\title{
Crisis? What Damned Crisis?
}

\author{
Iain Scobbie
}

It's not the bullet that kills you, it's the hole. ${ }^{1}$

Catherine Parr Traill, ${ }^{2}$ an early English colonist in Canada, was of the opinion that, 'In cases of emergency, it is folly to fold one's hands and sit down to bewail in abject terror: it is better to be up and doing'. ${ }^{3}$ But faced with crises, whether international per se or where the international impinges upon the domestic sphere, what do international lawyers do? What should they, or rather we, do?

In 2004, Paul Romer, then a professor at Stanford University and subsequently a Nobel Prize Winner in Economic Science, when discussing the increasing competition that US industry faced from rising educational levels abroad, observed that 'A crisis is a terrible thing to waste'. ${ }^{4}$ This was not a negative comment, but more a call to arms, a call to address an emerging and potentially challenging and possibly detrimental state of affairs. It has an affinity with Hilary Charlesworth's adage that:

International lawyers revel in a good crisis. A crisis provides a focus for the development of the discipline and it also allows international lawyers the sense that their work is of immediate, intense relevance. ${ }^{5}$

1 Laurie Anderson (1977)

2 See Charlotte Gray, Sisters in the Wilderness: The Lives of Suzanna Moodie and Catherine Parr Traill (Penguin 200o). It must be admitted that neither Mrs Moodie nor Mrs Traill would have approved of the original title of this chapter which was somewhat more emphatic.

3 Catherine Parr Traill, The Canadian Settler's Guide, chapter titled 'Fire' (first published 1855, 7th edn, Toronto, 1857) 194, 196.

4 See Jack Rosenthal, 'A Terrible Thing to Waste' New York Times (New York, 31 July 2009) <https://www.nytimes.com/2009/o8/o2/magazine/o2FOB-onlanguage-t.html> accessed 23 March 2021.

5 Hilary Charlesworth, 'International Law: A Discipline of Crisis' (2002) 65 MLR 377; compare Rebecca Ingber, 'Interpretation Catalysts and Executive Branch Legal Decisionmaking' (2013) 38 Yale J Int'l L 359 . 
Another way to perceive the law-generative capability of a crisis might be to classify it as a 'Grotian moment' - 'a transformative development in which new rules and doctrines of customary international law emerge with unusual rapidity and acceptance'. 6

But is this a correct or an appropriate way for us, as international lawyers, to react to a 'crisis'? The initial question that must be addressed is not 'what is a crisis?', but to go one step further than that to ask who decides when a 'crisis' exists? Who controls the narrative? This question has become more acute given the blossoming of the phenomenon of 'fake news', which always was there, but which has been magnified by pernicious social media accounts which frequently target conspiracies and allegations to recipients who are thought to be susceptible. Legally this can be mirrored by the knee-jerk generation of 'tabloid scholarship', ${ }^{7}$ which all too instantaneously offers up clear-cut analyses and solutions in (social) media and blogs, without pause for reflection or consideration of their wider systemic implications. And all the time this can be augmented by conscious and deliberate misdirection by political élites who, like magicians, distract their audience to get it to focus on some unimportant object instead of where the sleight of hand is actually happening, away from their mis-governance, mis-management, or sheer incompetence in the conduct of public affairs.

Just like Hilary Charlesworth's international lawyers, politicians also thrive on 'crises'. As a professional class, they need to be seen to be doing 'something', characteristically passing yet more laws domestically while talking externally to other governments and politicians, or at international fora such as summits or within intergovernmental organisations, conspicuously governing, dealing with 'crises', whether real or manufactured, in order to justify their continued existence, power, and influence. Much political discourse has degenerated into a 'war' on everything - the war on COVID, the war on drugs, the war on terrorism, the war on the 'other' however the 'other' is defined. The rhetorical trope is not one of challenges to be faced, but rather one of conflict. The notion of 'crisis' has been weaponised to achieve political ends, all too often at the expense of civil liberties and human rights, in which law is expected to play the role of handmaiden and facilitator. Should we, us international lawyers and as international lawyers, be complicit in this process?

It is manifestly obvious that the COVID pandemic constitutes a crisis, regardless of how one defines a 'crisis', but would an appropriate response be

6 Michael P Scharf, Customary International Law in Times of Fundamental Change: Recognizing Grotian Moments (CUP 2013) 5 .

7 I owe this term to Joe Powderly of the University of Leiden. 
the generation of new 'law' or should it rather be a question of the adoption of a new and appropriate regulatory regime, or a more assiduous implementation of existing regulations, rather than a change in the 'law' as such? Further, even if additional measures were to be adopted, it seems likely that these would be embodied in written instruments rather than through the emergence of new customary law, and one might even question if these could embody propositions of a 'fundamentally norm- creating character such as could be regarded as forming the basis of a general rule of law'.

There should be reservations about the desirability of international lawyers advocating for the deviation from or replacement of established doctrine, either by the generation of new custom or through the radically different interpretation of settled propositions, when faced with a 'crisis'. It can be understood why politicians might want to do this, in order to pursue or consolidate their quest for power and not infrequently material gain, but why should lawyers? In the interests of honesty, I should admit that I generally subscribe to e. e. cummings' poetic definition of a politician which has an added force in these apparently 'post- truth' times where 'alternative facts' are given gospel credence-'a politician is an arse upon which everyone has sat except a man'9 or, for that matter, a woman. I must concede that there are some exceptions to this rule, but we shall get to exceptions to rules later.

But what is a 'crisis'? Apart from physically material episodes such as a pandemic, natural disasters like earthquakes or tsunamis, famines or drought, situations which insurers might term 'acts of God', 'crises' tend to be situations which are dependent upon, are engineered by, or involve human agency in some significant if not critical way. ${ }^{10}$ These are different types of 'facts'. The former can be classified as 'brute' facts, simply physical or material phenomena, but the latter depend on the application of an interpretative schema which identify them as 'crises' and thus may be classified as institutional facts:11

$8 \quad$ North Sea Continental Shelf case (Federal Republic of Germany v the Netherlands) [1969] ICJ Rep 3, 42, para 72.

9 e. e. cummings, $1 \times 1$, 'No. 10' (Henry Holt 1944).

10 I am well aware that some famines result from direct human agency, whether politically motivated or as the result of armed conflict, such as the Povolzhye famine in the Soviet Union in 1921-22, or that in 1932-33 in which the forced collectivisation of agriculture was a significant contributing factor, or the Great Chinese Famine of 1959-61 in which the Communist Party's Great Leap Forward policy was closely implicated, or the 2017 famine in Sudan and the current crisis in Yemen which have been exacerbated by armed conflict, but others are predominantly 'natural'.

11 For an account of the notion of brute and institutional facts, see, e.g., Neil MacCormick, Institutions of Law: An Essay in Legal Theory (Oup 2007); and Neil MacCormick, Rhetoric and the Rule of Law: A Theory of Legal Reasoning (OUP 2005) especially ch. 1; and also 
those facts that depend not only on some physical events and occurrences which are supposed to have taken place, but also on an interpretation of these (and/ or other) events or occurrences in terms of some stable set of norms (either institutional or conventional norms) of conduct or of discourse. ${ }^{12}$

In short, when faced with a situation which is not a mere material brute fact, identifying a situation as a 'crisis' depends on interpretation, but who makes this decision, who controls the narrative?

It could often be that this determination is made from a relatively detached and objective standpoint by recognised experts using quantifiable or statistical criteria, for example, the claim that there has been a crisis in opioid prescription drug abuse in certain areas of the United States, but when we are dealing with international affairs this type of metric is often lacking and claims of 'crises' all too often impinge on matters of 'politics' and/or 'security' in one way or another. This type of claim depends inexorably on presentation and the selection of facts, issues, and arguments, all of which involve the rhetorical technique of 'presence', the argumentative concentration on particular factors in order to stress their importance while discounting or de-emphasising other factors. The selection of data, topics, and modes of argument is inevitable in the construction of any narrative:

choice is ... a dominant factor in scientific debates: choice of the facts deemed relevant, choice of hypotheses, choice of the theories that should be confronted with the facts, choice of the actual elements that constitute facts. The method of each science implies such a choice, which is relatively stable in the natural sciences, but is much more variable in the social sciences.

By the very fact of selecting certain elements and presenting them to the audience, their importance and pertinency to the discussion are implied. Indeed, such a choice endows those elements with a presence, which is an essential factor in argumentation. ${ }^{13}$

Iain Scobbie, 'Legal Theory as a Source of International Law: Institutional Facts and the Identification of International Law' in Samantha Besson and Jean d'Aspremont (eds), The Oxford Handbook on the Sources of International Law (OuP 2017) 493.

12 MacCormick, Rhetoric and the Rule of Law (n 10) 65.

13 Chaïm Perelman and Lucie Olbrechts-Tyteca, The New Rhetoric: A Treatise on Argumentation (John Wilkinson and Purcell Weaver trs, University of Notre Dame Press 1969) 29, 116: originally published as La Nouvelle Rhétorique: Traité de l'Argumentation (Presses Universitaires de France 1958). 
The content of any argument is simply selective, emphasising some factors while ignoring others, and this is never disinterested but is geared towards the picture its author wishes to present, and to present persuasively, in order to justify action in response to the perceived 'crisis'. But it is equally inexorable that different interpretations may be constructed of the same 'crisis', and that a response justified by one party may be contested and perhaps even seen as manifestly unlawful by another. How should we international lawyers react to these competing claims?

Martti Koskenniemi has observed that when he worked for the Finnish foreign ministry, politicians seeking international legal advice saw every situation as a 'new, exceptional, crisis'. The legal adviser's function was to link this back to precedents, to 'tell it as part of a history', and thus to present it as meshed in 'narratives in which it received a generalizable meaning' in order that the politician 'could see what to do with it'.14 But is this always possible? Faced with demands that some new 'crisis' exists, whether emanating from politicians or from traditional or social media which claim to reflect 'public opinion', pressure might build on lawyers to proffer novel 'legal solutions'. The claim that an international 'crisis' exists can all too often give rise to an existential dread on the part of international lawyers which causes us to question whether our professional lives, if not that of the very profession itself, have meaning, purpose, or indeed any value at all apart from keeping ourselves in a job.

This can lead to a normative panic, as these 'crises' almost seem to require some proactive reaction by lawyers, some attempt to meet the perceived exigencies of the situation which aims at providing a 'solution'. This may often involve norm entrepreneurship, where novel interpretations of existing norms are proposed or claims are made that the existing normative framework is inadequate and must be replaced. Frequently these proposals entail a plea to exceptionalism in one form or another - that the situation is completely unprecedented; that the State concerned is facing threats which are unique to it and to no other; or that the circumstances demand that an exception be made to existing doctrine.

During a 'crisis', we international lawyers face the peril of succumbing to the accommodation of political pretensions, descending into the apologetic justification of State behaviour: courting patronage, international lawyers all too often applaud the emperor's new clothes. As Philip Allott has observed,

14 Martti Koskenniemi, 'International Law in Europe: Between Tradition and Renewal' (2005) 16 EJIL 113, 120. 
"international law is left speaking to governments the words that governments want to hear", ${ }^{15}$ and thus remains marginal in the international system:

International law has been neither very threatening nor very useful to the politicians and the diplomats". ${ }^{16}$

Examples of international lawyers facilitating the legal justification of States' desires and bending to political winds are not lacking, especially in times of perceived 'crisis'. For example, Richard Falk has observed that, although not inevitable, the outcome of the application of New Haven analysis to a given issue 'had an uncomfortable tendency to coincide with the outlook of the US government and to seem more polemically driven than scientifically demonstrated'17 - exhibiting a 'penchant for applying their theory in justification of U.S. foreign policy'. 18

This should not be surprising given the foundational objectives of the New Haven School. Its genesis lay in the Second World War and the emergence of communism as an international political force. In launching their project at the height of the war, New Haven's founding fathers, Harold Lasswell and Myres McDougal, argued that, when law schools in the United States reopened after hostilities ended, they should be 'a place where people who have risked their lives can wisely risk their minds'. ${ }^{19}$ Their aim for legal education was to provide systematic training for policy-makers attuned to 'the needs of a free and productive commonwealth':

15 Philip Allott, Eunomia: New Order for a New World (oup 1990, reprinted 2001) 296, 16.1. The text of the reprint usefully retains the pagination of the first edition, but is augmented by a lengthy new preface which summarises the core ideas of Allott's thought and replies to the principal criticisms made to Eunomia on its first appearance. For commentaries on Allott's work, see the symposium 'Philip Allott's "Eunomia" and "The Health of Nations", Thinking Another World: "This cannot be how the world was meant to be"' (2005) 16 EJIL 255; and Iain Scobbie, " "The holiness of the heart's affection": Philip Allott's Theory of Social Idealism' in Alexander Orakhelashvili (ed), Research Handbook on the Theory and History of International Law (Edward Elgar 2011) 168.

16 Allott, Eunomia (n 14) 297, 16.3.

17 Richard Falk, 'Casting the Spell: the New Haven School of International Law', (1995) 104 Yale LJ 1991, 20o1; and Harold H Koh, 'Is There a "New” New Haven School of International Law?', (2007) 32 Yale J Int'l L 559, 563.

18 Falk (n 16) 1997.

19 Harold D Lasswell and Myres S McDougal, 'Legal Education and Public Policy: Professional Training in the Public Interest' (1943) 52 Yale LJ 203, 292. 
The proper function of our law schools is, in short, to contribute to the training of policy-makers for the ever more complete achievement of the democratic values that constitute the professed ends of American polity. ${ }^{20}$

On the other hand, the ideologically competing pre-perestroika Cold War Soviet theory of international law, as exemplified in the writings of Grigorii Tunkin, ${ }^{21}$ was so firmly rooted in Marxist-Leninist doctrine that, at times, it seemed simply to amount to taking the dogma for a walk.

But this malleability to the pressures of political exigencies need not always be the case. Take the example of Gerald Fitzmaurice in relation to the Suez Crisis of $1956 .{ }^{22}$ Following Egypt's nationalisation of the Suez Canal, the United Kingdom government wanted to take action to assert control over the canal through the use of armed force. Fitzmaurice was then legal adviser to the Foreign Office and strenuously denied that a lawful response to nationalisation could lie in the use of force. His lines of communication to political decision makers were impeded and blocked, and his advice ignored:

when the Minister of State at the Foreign Office, Sir Anthony Nutting, recommended that Fitzmaurice should be brought in 'on a matter which involved taking the law into our own hands', [Prime Minister] Eden's response was that 'Fitz is the last person I want consulted. The lawyers are always against our doing anything. For God's sake, keep them out of it. This is a political affair.'. ${ }^{23}$

It is perhaps not a coincidence that Fitzmaurice was dismissive of the approach to international law adopted by the New Haven School - 'Aiming at order and

$20 \quad$ Lasswell and McDougal (n 18) 206; see also Falk (n 16) 1993.

21 See, eg Grigorii I Tunkin, Theory of International Law (William E Butler tr, Allen and Unwin 1974); and Grigorii I Tunkin, The Tunkin Diary and Lectures (William E Butler and Vladimir G Tunkin ed and tr, Eleven 2012).

22 See Lewis Johnman, 'Playing the Role of a Cassandra: Sir Gerald Fitzmaurice, Senior Legal Adviser to the Foreign Office' (1999) 13 Contemporary British History 46; Geoffrey Marston, 'Armed Intervention in the 1956 Suez Crisis: the Legal Advice Tendered to the British Government' (1988) 37 ICLQ 773.

23 Quoted Johnman (n 21) 56. Lord McNair, former President of the International Court, was equally scathing of the legal position adopted by the UK government, see Johnman (n 21) 59-6o; and Marston (n 21) 812-814. 
liberality, its concepts, by their very breadth, open the door to anarchy and abuse. ${ }^{24}$

These differences of approach highlight the question of the correct or appropriate relationship between the lawyer and the law, if this is perceived as a set of reasonably discernible principles to guide and evaluate behaviour, and the relationship between the lawyer and his or her client. How much strength does it take for lawyers to say 'no' to a client who is hellbent on setting in motion a manifestly unlawful train of events or, like Fitzmaurice, if they make their views known, will they simply be sidelined?

There is always the risk that lawyers may too easily identify with their client and the client's interests: this is an inherent danger in law which is an instrumental practice aimed at justifying claims and justifying action. It would be stupid to claim that us, we international lawyers, are apolitical, but as a class we must examine and take responsibility for our politics and for the consequences of our choices. The issue is one of integrity, both personal and professional, what I have called elsewhere 'Tom Franck's moral compass', ${ }^{25}$ as although law is instrumental, it should contain a vector of constraint as well as enablement. It does us no good and denies us credibility if we simply become lackeys to politics, swaying uncertainly as its winds blow hither and thither.

'Be careful what you wish for' should be our governing maxim. Lawyers' reasoning can too easily switch between advocacy in aid of a client and recourse to a more disinterested authoritative account of the 'law'. In times of 'crisis' the former can lead to argumentation which is atomised and asystematic, focusing on the particular issue while failing to consider the wider, and future, normative implications that an immediate reaction might entail. A descent into apology, proffering normative support to novel State conduct, too easily suggests that all State practice becomes relevant to some normative realignment, where the measures adopted in an 'emergency' become the new 'normal', in which every action or reaction is somehow thought to be relevant to a calculation of change.

We can, however, learn from 'crises'. They can demonstrate that the existing normative structure is inadequate to provide a robust answer or reaction to a

24 Gerald G Fitzmaurice, 'Vae Victis or Woe to the Negotiators! Your Treaty or 'Our' Interpretation of It?' (1971) 65 AJIL 358, 373 .

25 See Iain Scobbie, 'Wicked Heresies or Legitimate Perspectives? Theory and International Law' in Malcolm Evans (ed), International Law, ( $3^{\text {rd }}$ edn, oup 2010), Section v, 'The Decadence of Hegemonic Instrumentalism', referring to Thomas M Franck, 'Raising the Hoe: the New Clientage: Andy and Me at Vanderbilt Hall' (2009) 42 NYU J Int'l Law and Pol 11. 
given situation. There are two competing issues at place here: the notion of negative feedback and the doctrine of inertia. Negative feedback lies in the realisation that existing normative propositions are lacking in perspective or efficacy which can then lead to a search for a better crafted and more appropriate or desirable solution. ${ }^{26}$ The doctrine of inertia refers to the presumption that, failing contrary proof, an attitude adopted in the past should subsist and may be relied upon, because change requires justification. ${ }^{27}$ This was one of the major contributions to argumentation theory by Chaïm Perelman which provides a foundation for the ascription of the burden of proof in practical discourse, ${ }^{28}$ and which he argues underlies the rule of formal justice that what has been considered as valid in one situation will be considered valid in all similar situations. These two vectors, the opposition of stability and change, must be balanced and handled with discernment. The time to make lasting decisions is not at the height of a 'crisis' when a detached evaluation of which changes, if any, should be made can too easily be blunted by a kaleidoscopic blizzard of changing and mutating factors and immediate concerns. We need to take a step back, take a breath, take time to think, and not simply blindly react.

There needs to be a systemic analysis of the implications of any proposed changes; for instance, consider some relatively recent attempts to reformulate and widen the parameters of self-defence, ostensibly under the guise of the so-called crisis labelled the 'war on terror'. 29 These involve a number of intertwined strands of argument on the part of States, politicians, and lawyers who advocate for change, such as norm entrepreneurship; a desire to have or to

26 On negative feedback see, eg, FA von Hayek, Law, Legislation and Liberty (Routledge and Kegan Paul 1973-1979), especially Volume 1, Rules and Order (1973).

27 See Perelman and Olbrechts-Tyteca (n 12) s 27, 104-110, and s 52, 218-220; also Chaïm Perelman, Justice, Law, and Argument: Essays on Moral and Legal Reasoning (Reidel: Dordrecht: 1980) 27-28, 169 et seq. Perelman sees inertia as allowing the transition from normal to norm by way of argumentative justification, although he concedes that Hume's view that this is a logically illicit transition is valid (for instance at Justice, Law, and Argument (n 12) 28). Hume's argument is in David Hume, A Treatise on Human Nature (Clarendon Press 1739) §iri.i.1. On Hume's argument, see John L Mackie, Hume's Moral Theory (Routledge and Kegan Paul 1980) Chapter Four; and also Chaïm Perelman, Logique Juridique: Nouvelle Rhétorique (Dalloz 1976) paras 49, 99-101.

28 See Robert Alexy, A Theory of Legal Argumentation: The Theory of Rational Discourse as Theory of Legal Justification (Ruth Adler and Neil MacCormick trs, Clarendon Press 1989) ch. 4 .

29 For a more detailed examination of some of these issues regarding self-defence, see Iain Scobbie, 'Exceptions: Self-defence as an Exception to the Prohibition of the Use of Force' in Lorand Bartels and Federica Paddeu (eds), Exceptions in International Law (OUP 2020) 150. This volume contains a useful survey of both conceptual and substantive issues. 
create a normative framework which is meant to address perceived problems States argue are raised by non-State actors or armed groups; feelings of uncertainty and inadequacy in dealing with possible threats formulated abroad; and a confusion, which might be conscious, of legal categories which otherwise might be seen as distinct. Some of these attempts have been criticised and dismissed by doctrinal writings, such as the unreconstructed Bush doctrine of pre-emptive self-defence even in the absence of an imminent threat, ${ }^{30}$ while others have gained more traction, even though they might simply present discredited arguments anew.

One of the principal areas of controversy is that of self-defence against non-State armed groups which are located abroad. While a State taking action against a non-State armed group within its own territory might raise human rights questions, it does not raise issues related to the international law governing self-defence. Key questions here include whether a State may lawfully take armed action against a non-State armed group located within another State in the absence of invitation or consent when it deems that the latter is unable or unwilling to take effective or repressive action against that armed group to contain or end actual or threatened attacks planned or perpetrated by it; and what constitutes 'imminence' in relation to an anticipated attack. The latter might simply be the Bush doctrine revived.

Proposals of this type, such as the principles proposed by Daniel Bethlehem in 2012, are avowed attempts at norm entrepreneurship. He noted that much doctrinal commentary has discussed the question of resort to self-defence by States against imminent and actual armed attacks by non-State actors, but this has had little impact on governmental and military decision-makers as ' $[\mathrm{t}]$ here is little intersection between the academic debate and the operational realities'. In contrast, his principles were 'informed by detailed discussions over recent years with foreign ministry, defense ministry, and military legal advisers from a number of States who have operational experience in these matters'. ${ }^{31}$ In 2017, in expounding the United Kingdom government's understanding of 'imminence' in relation to invoking self-defence in relation to threats posed by non-State armed groups, the then UK Attorney General, Jeremy Wright, expressly endorsed the Bethlehem Principles, reiterating that these had been

30 See, eg, Christine Gray, International Law and the Use of Force ( $3^{\text {rd }}$ edn, oup 2008) 209-216, and also $4^{\text {th }}$ edn (OUP 2018) 248-253; and Christine Gray, 'The Bush Doctrine Revisited: the 2006 National Security Strategy of the USA' (2006) 5 Chinese JIL 555.

31 Daniel Bethlehem, 'Self-Defense Against an Imminent or Actual Armed Attack by NonState Actors' (2012) 106 AJIL 770, 773. 
informed by 'detailed official-level discussions.' ${ }^{32}$ The non-disinterested origin of these principles has attracted comment and criticism in scholarly reaction - for example, by two former legal advisers to the UK Foreign Office who stated that it was no doubt anticipated that a select group of governmental representatives might reach agreement among themselves when the UN membership as a whole could not.' ${ }^{33}$

One prominent aspect of this attempt to expand the parameters of selfdefence is the use of targeted killings by drones against specific individuals, the notion of 'personality strikes', who may be nationals of the State concerned, as opposed to 'signature strikes' which are employed against those who display alleged characteristics of terrorist activity or involvement. ${ }^{34}$ This seems to be an exercise in collapsing categories. The recourse to self-defence as a justification for engaging in targeted killings is ambivalent, blurring the borders between the ius ad bellum, the ius in bello through the invocation of the direct participation in hostilities by civilians who are members of non-State armed groups, and international human rights law, making issues liminal, as they exist neither here nor there.

Consider this statement made by then UK Prime Minister David Cameron in the House of Commons on 7 September 2015 regarding the targeted killing by a Royal Air Force drone of United Kingdom nationals, alleged to be members of the Islamic State armed group, and who were alleged to be involved in plotting terrorist attacks in the United Kingdom and other States. He said that as 'their intention was the murder of British citizens':

We took this action because there was no alternative. In this area, there is no Government we can work with; we have no military on the ground to detain those preparing plots; ... we had no way of preventing his planned

32 Jeremy Wright, 'The Modern Law of Self-Defence', (Speech at International Institute for Strategic Studies, London, 11 January 2017) 15 <https://assets.publishing.service.gov.uk/ government/uploads/system/uploads/attachment_data/file/583171/170111_Imminence _ Speech_pdf $>$ accessed 23 March 2021.

33 Elizabeth Wilmshurst and Michael Wood, 'Self-Defence Against Non-State Actors: Reflections on the "Bethlehem Principles"' (2013) 107 AJIL 39o, 391: see also, eg, Michael Glennon, 'Law, Power, and Principles' (2013) 107 AJIL 378; Mary Ellen O'Connell, 'Dangerous Departures' (2013) 107 AJIL 380, 384-385; and Victor Kattan, 'Furthering the "War on Terrorism" Through International Law: How the United States and the United Kingdom Resurrected the Bush Doctrine on Using Preventative Military Force to Combat Terrorism' (2018) 5 Journal on the Use of Force and International Law 97, 112-123.

34 For a critical analysis of this distinction, see Kevin Jon Heller, " 'One Hell of a Killing Machine”: Signature Strikes and International Law’ (2013) 11 JICJ 89. 
attacks on our country without taking direct action ... We were exercising the UK's inherent right to self-defence. There was clear evidence of these individuals planning and directing armed attacks against the UK ... given the prevailing circumstances in Syria, the airstrike was the only feasible means of effectively disrupting the attacks that had been planned and directed. It was therefore necessary and proportionate for the individual self-defence of the United Kingdom. ${ }^{35}$

Self-defence - ius ad bellum; planned attacks - ius in bello, under the rubric of direct participation in hostilities; inability to detain - human rights law; but which should be predominant? It is commonplace that legal reasoning is cumulative, but surely all the reasons should point in the same direction?

Targeted killings are only lawful within the context of an armed conflict, whether international or non-international, ${ }^{36}$ otherwise they are unlawful extra-judicial executions. There are two pertinent issues here. Does a claim of recourse to self-defence by a State against a purported non-State armed group automatically entail the existence of an armed conflict between them? If a claim of self-defence is being made by a State is there a sufficient intensity of conflict to determine that an armed conflict exists, or that its adversary is actually an organised armed group which is capable of being classified as a party to a conflict? ${ }^{37}$ If incidents perpetrated by a suitably organised group are sporadic and episodic, can the intensity of a purported conflict be hypothetical or potential where there is 'no specific evidence of where an attack will take place or of the precise nature of an attack, ${ }^{38}$ or even that such an attack might take place?

Let us suppose that, despite these reservations, an armed conflict may exist between a State and a non-State armed group and that the State conducts targeted killings extra-territorially under the rubric of self-defence. This entails conflict beyond and without borders, ripping off the territorial constraints identified by distinguished commentators such as Christopher Greenwood

35 House of Commons Debates, 7 September 2015, Vol. 599, Columns 25-26: see also the House of Lords and House of Commons Joint Committee on Human Rights Second Report of Session 2015-16, The Government's Policy on the Use of Drones for Targeted Killing, HL Paper 141/HC 574 (10 May 2016), Chapters 3 and 5; and Intelligence and Security Committee of Parliament, UK Lethal Drone Strikes in Syria, HC $115^{2}$ (26 April 2017).

36 On classification of conflicts, the leading work is Elizabeth Wilmshurst (ed), International law and the Classification of Conflicts (OUP 2012).

37 See Noam Lubell, 'The War (?) Against Al-Qaeda' in Wilmshurst (n 35), 421, 434-437.

38 Bethlehem (n 3o) 776: quoted and endorsed in Wright (n 31$) 17$. 
and Daniel O'Connell. ${ }^{39}$ Law, however, is reflexive: normative proposals and classifications made to govern others equally govern you. If a conflict can legitimately be taken abroad by the State, then can it not equally legitimately be brought home by the non-State armed group, making acts generally denounced as 'terrorism' be reclassified as acts of 'war'? During an apparently never-ending 'war on terror' are, for instance, civilian operators of weaponised drones legitimate targets, and their families and possibly neighbours collateral damage? Would such a reclassification make (civilian) populations think about what their politicians have wrought ostensibly in their name, and reflect upon the effects these decisions have had on people far away? We have to be careful what we wish for because it can bite back.

As international lawyers we must be rational and clear-sighted. In times of 'crisis' a seductive argument can too easily be made that because these are exceptional times or present exceptional challenges, exceptions or reclassifications or changes should be made to established doctrine or interpretation. International lawyers should tread cautiously and carefully weigh arguments in favour of these temptations and pressures which can all too easily become embedded in doctrine and unshackle States and politicians from normative restraints. All too often these claims are normatively localised, focusing on a narrow issue without regard to its systemic ramifications. We must be disciplined in our approach to our discipline in order to guard against a:

lawless science of our law, that codeless myriad of precedent, that wilderness of single instances ... ${ }^{40}$

Would it not be more honest for us international lawyers to acknowledge that State action in response to a given 'crisis' might be illegal rather to than dress it up in a spurious legal tinsel which glitters and whose only function is to distract us and others from the politicians' sleight of hand? When do we embrace responsibility for our discipline?

39 See Christopher Greenwood, 'The Relationship between ius ad bellum and ius in bello' (1983) 9 Review of International Studies 221; Daniel O'Connell, The Influence of Law on Sea Power (Manchester University Press 1975) ch. 9.

Alfred, Lord Tennyson, Aylmer's Field (first published 1864, MacMillan and Co 1891) 14. 